\title{
FOLK TRADITIONAL ART IN THE INDUSTRIAL REGION (ON THE EXAMPLE OF ARTISTIC PROCESSING OF AMBER IN THE KALININGRAD REGION)
}

\author{
Sergey Viktorovich Lebedev, \\ Doctor of Philosophical Sciences, Full Professor, \\ Head of Department of Philosophy \\ Higher School of Folk Arts (Academy) \\ 191186, St. Petersburg, Griboyedov canal, 2A \\ E-mail: servicleb@list.ru
}

Abstract. The article is devoted to the history and development of artistic processing of amber. This fishery emerged after 1945 with the join of part of the former East Prussia to Russia, and therefore can be considered the youngest artistic craft in Russia. Russian folk art is characterized by the fact that it is constantly reproduced in a variety of new forms and directions. As the historical experience of the Kaliningrad region shows, folk art can arise and develop in towns including large metropolitan areas in a historically newly populated territory.

Keywords: amber, East Prussia, Kaliningrad region, folk art, artistic processing of amber.

\section{Introduction.}

Two ideas are common in the ordinary consciousness of the folk art of Russia. First, it is believed that folk art originated in incredible antiquity. And, secondly, that it was "done" in the village. In principle, these judgments are fair in many respects. Indeed, many Russian arts and crafts developed in ancient times. For example, the art of carving on wood or bone appeared in the Neolithic era. In the depths of centuries, the early Slavs already had many elements of the future Russian traditional art. The ornaments of ceramic products of the early Slavs, which were found in the middle 
Dnieper and dating the period from the $3^{\text {rd }}$ century $\mathrm{BC}$ to the $2^{\text {nd }}$ century $\mathrm{AD}$, are almost identical to the ornaments of Russian similar products of the $19^{\text {th }}$ century [7]. Already from the $4^{\text {th }}$ to the $9^{\text {th }}$ centuries, the Slavs who lived on the middle Dnieper, were famous for the developed jewelry art. They used gouged enamel and knew the technique of grain [6].

However, it is fair to note that Russian folk art developed during the rapid growth of the factory industry in Russia. Some famous Russian art crafts, such as lacquer miniature, appeared in the $20^{\text {th }}$ century [7]. In the late $1960 \mathrm{~s}$, Varnavian bone carving appeared. Thus, a unique feature of Russian traditional applied art can be considered that it has continued to develop in the industrial and post-industrial era.

Also, the opinion about the only "village" origin of folk art is not quite fair. The peculiarity of Russia was that large industrial cities and the surrounding industrial agglomeration were also centers of folk arts and crafts in the past and in the present. Tula, Yekaterinburg, Nizhny Tagil, and some other industrial cities were also centers of folk arts and crafts. Rostov enamel is associated with the ancient city of Rostov the Great, blackening on silver was born and acquired its characteristic features in Veliky Ustyug (or Great Ustyug), Zlatoust engraving on steel also originated in the Ural factory town of Zlatoust. Finally, St. Petersburg, built by Peter the Great as a fundamentally new "European" city symbolizing a complete break with the whole of the old traditional Rus, also became one of the centers of traditional Russian folk arts.

\section{Results.}

Among the reasons why towns became centers of new artistic crafts, it is possible to allocate that peasants often simply did not accept innovations as they did not need them, but at all not owing to their "darkness" and "ignorance" [5, 27-28]. However, the burghers and artisans of towns, peasants of commercial villages, as well as residents of factory settlements, were very receptive to new artistic trends, focused on the market, and therefore they took into account the tastes and needs of buyers from different social strata. At the same time, these creative artists belonged to the traditional layers of Russian society in their mentality and life. In the Soviet period of national history, folk art continued to develop. 
Cultural development of any historical epoch is determined not only and not so much by "high" kinds of art. The artistic style of the time is also determined by the products of decorative art. The art critic Vladimir V. Stasov wrote, “... real, integral, healthy art in itself exists only where the need for elegant forms and in a constant artistic appearance has already extended to all the hundreds of thousands of things that daily surround our lives. Real folk art was born only where my staircase is graceful, and also a room, a glass, a spoon, a table, a cupboard, and a stove are graceful, and so until the last object" $[11,540]$.

The art of artistic processing of amber can be called among the "youngest" in age Russian artistic crafts, at the same time, achieved world recognition. This direction was born after 1945 in the Kaliningrad region, the former East Prussia.

Amber is a petrified resin of ancient coniferous trees [13]. It is widely used in jewelry. Amber fields are situated in many regions of the world, but almost $90 \%$ of the world's amber is concentrated on the south-eastern shore of the Baltic Sea, in the territory of the modern Kaliningrad region of Russia. Especially, there are a lot of amber in the Sambian Peninsula.

Amber has been known to mankind since the most ancient times. At the first sites of primitive man including very remote from the Baltic coast, archaeologists found pieces of processed amber. About 6 thousand years ago, amber from the shores of the Baltic Sea began "to spread" around the world. The scale of trade is evidenced by the discovery of a treasure on the territory of Poland that is dated to the border of the eras. This treasure contained 1500 kilograms of raw amber.

Archaeologists found amber in the tombs of Egyptian pharaohs of early dynasties. In particular, the crown of Pharaoh Tutankhamun was decorated with Baltic amber. In Homer's Odyssey, it was said that amber was used to make ornaments and decorate the rooms of royal palaces. In the Roman Empire, amber was widely used in the manufacture of wine vessels, temple bottles for incense. Wealthy Romans decorated the inner chambers of their houses with amber too.

The Roman scientist Cornelius Tacitus (ac. the $1^{\text {st }}$ and the early $2^{\text {nd }}$ centuries) noted that amber of the Baltic Sea was collected by the people of "Aesti" (i.e., 
"Eastern"). They meant the Prussians, i.e., the inhabitants of the territory between the rivers Neman and Narev. According to Tacitus, "They (Aestii) also search the sea too and harvest amber alone from all on his shoals and even on really coast... However, what its nature is and where it comes from, they, being barbarians, do not seek... It had even laid long with them (without use) among the other dregs of the sea until our passion for luxury made it famous. They do not use it at all. It is collected in a rough form, brought to the market without any finishing or cutting, and they get paid for it with surprise" [12, 372].

At the early $13^{\text {th }}$ century, the amber-rich lands of the Prussians were conquered by the knights of the Teutonic Order. The conquerors claimed all amber reserves as their property. Extraction and trade of amber could be only conducted the order's brothers. Any illegal extraction of amber was punishable by death. Vogt (one of the leaders of the order) Anselm von Losenberg went down in history that he torture and executed even for a small hidden piece of amber. It is no coincidence that among the miners of amber there was a belief that the ghost of Losenberg walked among the Baltic waves and threatened death to all who extracted amber. Later there was the state of Prussia in the order's possessions. The sale of amber became one of the main sources of income. At the same time, Prussia was quite a rich state, which united Germany later.

Amber was known in Rus since ancient times. Archaeologists found a very numerous amber jewelry during the excavations of ancient Rus cities in the layers from the $10^{\text {th }}$ to the $13^{\text {th }}$ centuries. As we can be seen from the excavations of archaeologists, there were workshops for processing amber in large cities, especially, in the capitals of the specific principalities. Amber was mined in some Rus' lands, for example, in Volyn. Due to the close ties with the Baltic states, Baltic amber was still used mainly in Rus. Amber was traditionally called Alatyr in Rus. Poetically, Alatyr was also called white-combustible stone or the stone of all stones. Alatyr is often mentioned in epics, folk and spiritual songs, as well as in spells and conspiracies. It was also often called frankincense. The name was explained by the fact that the ignited amber is smoldering for a long time spreading a pleasant smell, like real 
frankincense. For this reason, in Rus, the temples practiced the burning of amber for several centuries, because Baltic amber was much cheaper than frankincense from the Middle East.

Nevertheless, artistic processing of amber in Russia began generally developing after the Second World War only when the part of the former East Prussia was joined to the USSR after the war under the name of the Kaliningrad region. In Russia, this region has the smallest territory, 15.8 thousand square kilometers, or $0.3 \%$ of the country's territory [8]. The organized settlement of the Kaliningrad region began in that time $[9,936]$. The Kaliningrad scientist Yuri Zverev noted, "In the economic and geographical literature there is a term of the countries of resettlement capitalism. In this sense, the region can be called as the region of resettlement socialism with all its pros and cons" $[4,47]$.

There are 22 regional towns, half of which have less than ten thousand inhabitants, four urban-type settlements and just rural settlements. At the same time, the region, where statistics refer to 213 thousand people as rural residents, has practically no villages in the traditional Russian sense. By the way, the farms, so peculiar to the nearest neighbors from the Baltic states, are also absent. There are small villages whose inhabitants are engaged in agriculture. However, the urban lifestyle prevails for them. There are many universities in the region. The average level of education is higher than the national one. As you can see, Kaliningrad residents are mostly citizens with a high level of education. However, it is the region where the Russian artistic craft of amber processing was born.

There was not a single amber expert among the migrant settlers. However, aesthetic sense and ingenuity quickly led to the emergence of amateur amber jewelers in the new Russian land. At the same time, all the German specialists in the extraction and processing of amber left East Prussia taking all the production secrets with them. Almost all amber deposits were severely damaged as a result of military operations. In addition, the Germans tried to destroy all equipment and documentation. Finally, due to a number of political circumstancesб masters of amber processing from the neighboring Baltic republics did not come to Kaliningrad in the first decade and a 
half of the region's existence when the local art craft was born. Thus, the extraction and artistic processing of amber began from scratch in Russia. And it is possible to be amazed that Russian masters created their own special Kaliningrad school of artistic processing of amber very quickly.

In 1947, an Amber combine was established in the settlement of Yantarny (Amber's). Amber has been mined and artistically processed there. In the first decade of operation, the plant was producing fairly simple products: necklaces, bracelets, pendants, brooches, cigarette holders, cufflinks, and buttons. From the very beginning, novice artists of amber craft tried to create their own style with success, although, due to lack of experience, the first amber products were quite primitive. Decorations mostly repeated the forms of leaves, berries, and fruits. Amber was even tinted for greater naturalness and "beauty" of it. Noble metals, especially gold and silver were widely used in work with amber.

In the late 1950s, Kaliningrad masters moved from imitation and the first, still simple products to create more fundamentally new artistic products than the former East Prussian. Kaliningrad jewelry were also distinguished by the peculiarity of the artistic method from what was cultivated in Latvia and Lithuania. Amber was being mined in these republics for many centuries. Baltic jewelers did not aim to give an amber product a certain, predetermined shape. They emphasized its natural shape and color only. Kaliningrad style creatively combined the Prussian desire for decoration and the Baltic desire to preserve the naturalness of the "sunstone".

Kaliningrad residents, in addition to mass production for the general consumer, began to create original thematic compositions in these years: monumental vases, panels, amber-decorated boxes, and souvenirs. The imperial monumentalism, peculiar to all art of that time, so-called Stalin Empire, was reflected in such largesized products. As a result, works acquired heaviness also for the reason that the masters who arrived to combine, were carvers on other stones - jasper or marble [3, 680]. The plant continued producing serial products in hundreds of thousands of copies, but author's art products using various jewelry techniques, also created too. 
In 1959, the government of the USSR issued a decree On Improving the Range, Quality and Decoration of Amber Products. Then artists and art critics were involved to use amber. Achievements in the field of amber of the Baltic peoples were creatively processed. It became possible to speak about the formation of the Russian Kaliningrad amber school. The masters who worked in the 1960s at the Kaliningrad amber plant, became the founders of the Kaliningrad school of amber processing: A. Meos, A. Popov, A. Kvashnin, E. Lis, V. Mityanin, R. Benislavsky, A. Yaroshenko and V. Shorokhov [9, 682]. In 1961-1962, the all-Union competition for the best sample of amber product was held in the USSR. The competition received 439 applications made in sketches and material from many cities and republics of the state including the Baltic states. However, the victory went to Kaliningrad resident A. Popov. This was a milestone in the all-Union and then world recognition of the Kaliningrad school of artistic processing of amber [10, 682].

Since the second half of the 1960s, amber boom started in the USSR. Various amber products (not all of which can be called artistic) were then offered by most jewelry stores in the country. It got reflection in the quality of the products, because amber specialists had to produce according to the plan, i.e., a huge number of amber products without taking into account their artistic value. However, the Soviet consumer was not spoiled and one was quite satisfied with the amber products offered by the trade.

With the collapse of the USSR, the amber industry was gripped by a protracted crisis. Hundreds of new private enterprises began to emerge. They quickly react to the latest fashion trends. The state monopoly on the extraction and processing of amber lost its influence, and the amber industry passed into private hands in many respects. Customers' tastes also changed. Then buyers sought to purchase exclusive handmade jewelry of the famous master.

Gradually the crisis was overcome. A strong impetus to develop the fishery was done by the work on the restoration of the Amber room in Tsarskoye Selo. Modern jewelers restored European techniques of "sunstone" processing of the $17^{\text {th }}$ and $18^{\text {th }}$ centuries, which were almost forgotten in Europe. Modern Russian are not afraid to 
combine amber with metals, bone, wood and other elements masters in the new century. Great demand for Baltic amber arose due to a sharp increase in the tourist flow from Asia, especially, from China where amber is quite popular.

The rise of the amber business is the fact that, according to the official site of administration of Kaliningrad region, more than 150 enterprises with over 3,000 workers and specialists involve processing of the "sunstone" in the region [1].

Due to the high demand for amber, the cost of amber products sharply increased, so many fakes began appearing on the market. However, approximately $95 \%$ of amber on the international market is a high-quality material. Cost factors include color, transparency, intensity of color and lack of defects. The classic color of amber is considered to be golden and cognac color $[2,67]$.

\section{Conclusion.}

Thus, the artistic processing of amber has become native Russian direction in art. We have to note that the artistic processing of amber is completely related to Russian folk applied art. Amber jewelry has become one of the calling cards of the national jewelry art.

\section{References:}

1. Where Amber Industry Specialists Are Trained in our Region. - URL: https:// www.strana39.ru/news/obuchenie/87632/gde-v-nashey-oblasti-gotovyatspetsialistov-yantarnoy-otrasli.html (in Russian)

2. Dronov D.S. (2018). Gemology. Part 2. Textbook for Bachelors. Direction of Training of "Decorative and Applied Arts and Crafts". The Profile of "Art Metal (Jewelry)”. Higher School of Folk Arts, St. Petersburg, Russia. (in Russian)

3. Zhirikova N. (2018). Amber Art Craft of Russia. Russian people. Encyclopedia of Folk and Decorative Arts [scientific editor-compiler S.V. Lebedev]. Vol. 2. Institute of Russian Civilization, Moscow, Russia. (in Russian).

4. Zverev Y. (1997). Kaliningrad Region of Russia in a New System of Geopolitical Coordinates. Ethnic and Regional Conflicts in Eurasia. Vol. 2. The Whole World, Moscow, Russia. (in Russian) 
5. Krasnobaev, B.I. (1985). Main Features and Tendencies of Development of Russian Culture in the $18^{\text {th }}$ Century. Essays on Russian Culture of the $18^{\text {th }}$ Century. Vol 1. Moscow, Russia. (in Russian)

6. Lebedev S.V. (2017). Kiev Land or Actually Little Russia. Ethnic history. URL:

https://ruskline.ru/analitika/2017/05/06/kievskaya_zemlya_ili_sobstvenno_malorossi ya/ (in Russian)

7. Lebedev S.V. (2019). Traditional Applied Art of Russia in the Soviet Era: Successes and Problems - URL: https://cyberleninka.ru/article/v/traditsionnoeprikladnoe-iskusstvo-rossii-v-sovetskuyu-epohu-uspehi-i-problemy (in Russian)

8. Lebedev S.V. (2015). Russia Amber. Ethnic History of the Kaliningrad Region. Russian Folk Line https://ruskline.ru/analitika/2015/01/16/rus_yantarnaya (in Russian).

9. Lebedev S.V. (2015). Colonization as an Indicator of the Vitality of the Russian People. Health is the Basis of Human Potential: Problems and Ways of their Solution. 19-21 November 2015. The Works of the all-Russian Scientific and Practical Conference with International Participation. Vol. 2. RSPU named after A.I. Herzen, St. Petersburg, Russia. (in Russian)

10. Mashkova O. (2018). Amber Museum in Kaliningrad. Russian People. Encyclopedia of Folk and Decorative arts [scientific editor-compiler S.V. Lebedev.]. Vol 2. Moscow: Institute of Russian Civilization, Moscow, Russia. (in Russian)

11. Stasov V.V. (1954). Selected Works: in 3 vols. Vol. 1. Moscow, 1954.

12. Tacitus K. (1969). On the Origin of the Germans and the Location of Germany. Select Works: in 2 vols. Vol. 1. Leningrad, Russia (in Russian)

13. Bukanov V.V. (2019). Amber. Colored Stones: Encyclopedia. - URL: http:// gems.minsoc.ru/articles/amber (in Russian). 